\title{
Performance, Intestinal Histomorphology, and Blood Variables of Broilers Fed Amaranth Grain in Pellet Diet
}

\author{
A. H. Alizadeh-Ghamsari*, S. A. Hosseini, M. R. Soleymani, \& R. Nahavandi \\ Animal Science Research Institute of Iran, Agricultural Research, Education, and Extension Organization (AREEO), \\ Karaj, Iran, Postal Code: 3146618361 \\ *Corresponding author: amir3279@gmail.com \\ (Received 03-06-2020; Revised 29-07-2020; Accepted 05-08-2020)
}

\begin{abstract}
An experiment was conducted to evaluate the effects of amaranth grain in pellet diet on performance, intestinal morphology of jejunum, and selected blood variables of broilers. A total of 400 seven-day-old Ross 308 male broilers were allocated to 4 treatments with 5 replicates of 20 birds in a completely randomized design. Experimental treatments were included 4 levels of amaranth grain $(0 \%$ (control), $2 \%, 4 \%$, and $6 \%)$ in the isonitrogenous and isocaloric pellet diets. During the experiment, body weight (BW) and feed intake (FI) were recorded weekly and average daily gain (ADG), feed conversion ratio (FCR), as well as European broiler index (EBI), were calculated. On day 42, blood sera and jejunal tissue samples were obtained from 6 birds per replicate to evaluate morphological variables including villus height, villus width, and crypt depth, as well as selected blood variables. Although intestinal morphology and average daily feed intake (ADFI) were not influenced by experimental treatments, birds receiving $2 \%$ amaranth grain showed higher BW, ADG, and EBI compared to the other treatments $(\mathrm{p}<0.05)$. Chickens fed with diets including various levels of amaranth grain showed the decreased low-density lipoprotein (LDL) and cholesterol concentrations in the blood sera and reduced relative weight of abdominal fat compared to the control $(\mathrm{p}<0.05)$. Dietary addition of amaranth grain up to the level of $2 \%$ could improve the performance of broiler chickens, decreased blood cholesterol and LDL levels, and relative weight of abdominal fat which may have healthful effects on the birds and broiler-meat-consumers.
\end{abstract}

\section{Keywords: amaranth grain; broiler chickens; growth performance; histomorphology; biochemical blood variables}

\section{INTRODUCTION}

In the present time and future, extensive investigation for ecological plant resources is so important for obtaining sustainable food and feed security. Not many years ago, human and livestock consumed more than one thousand species of plants; however, today one hundred and fifty species are only cultivated on a worldwide scale and most of the international requirement for calorie and protein is provided by five plant species: wheat, maize, potato, soybean, and rice (Sing et al., 2020). For this reason, rediscovering beneficial, often forgotten crops have been in consideration of many nutritionists all over the world during the last decades (Boreli et al., 2020).

In the last 35 years, plant amaranth (Amaranthus spp.) has been recognized as a capable plant mostly because of its resistance to warmth, diseases, and water shortage, as well as the high number of nutritive compounds in both leaves and seeds (Venskutonis \& Kraujalis, 2013; Martinez-Lopes et al., 2020). The grain protein content of this plant is generally noticeable, about 14-18\% (Martinez-Nunez et al., 2019). Amaranth grain contains a high-quality protein with an excellent balance of amino acid, which is better than many cereals and some legumes (Shevkani et al., 2014). Mota et al. (2014) characterize the amino acid composition of amaranth (Amaranthus caudatus) and also two other pseudocereals including buckwheat (Fagopyrum esculentum) and Quinoa (Chenopodium quinoa) and conclude that all these pseudo cereals contain a rich source of essential amino acids and maybe an alternate ingredient in gluten-free diets of human. Amaranth albumin and globulin are relatively rich in lysine and sulfur amino acids, while glutelin is a source of phenylalanine, tyrosine, and Leucine (Lopez et al., 2018). Amaranth grain also contains twice the level of calcium in milk, five times the level of iron in wheat, higher potassium, phosphorous, zinc, vitamin E, and folic acid than cereal grains (Ndungu et al., 2017).

In monogastric animal nutrition, the suitability of amaranth grain was previously shown in rabbit (Molina et al., 2015), broilers (Longato et al., 2015; OrczewskaDudek et al., 2018), and also quails (Szczerbińska et al., 2015). Amaranth grain has been used in many countries as a source of plant protein for chickens, pigs, and rabbits especially in the tropical and subtropical areas (Peiretti, 2018). However, Yaghobfar et al. (2014) reported dietary inclusion of amaranth grain (Amaranthus 
hybridus) in the proportion of $5 \%$ and more resulted in lower performance parameters of broilers than control. This issue can be due to the presence of antinutritional factors like trypsin inhibitor, phenols, and tannins (Reyes et al., 2018). Treatments like popping, autoclaving, extruding, and pelleting may be moderately or entirely degraded antinutritional compounds (Gamel et al., 2006; Siwatch \& Yadav, 2017; Thakur \& Kumar, 2019).

Due to the lack of information about the effects of dietary addition of amaranth grain in broiler pellet diet in subtropical regions of Southwest Asia, this research was conducted to evaluate dietary inclusion of amaranth on productive traits, intestinal morphology, and selected blood variables of the broiler chickens in Iran.

\section{MATERIALS AND METHODS}

\section{Ethical Standards}

The experimental methods used in the present study were approved by the Animal Ethics Board of Animal Science Research Institute of Iran (Approval No. 08415).

\section{Birds, Housing, and Rearing Conditions}

The research was conducted at the Research Poultry House of Animal Science Research Institute of Iran (Kara, Iran). Four hundred one-day-old male broil- er chickens (Ross 308) were acquired from an industrial hatchery (initial BW $40 \pm 0.5 \mathrm{~g}$ ). During the first six days, all birds were fed a common diet (Table 1) based on Ross 308 recommendations (Avaigen, 2014). At the age of seven days, the chickens with similar weight (BW $170 \mathrm{~g} \pm 0.4$ ) were distributed in 20 pens after three hours of fasting. Three square meter space was considered for each pen, and wood shaving was used to cover the floor of the pens. The initial temperature of the house was kept at $33 \pm 2^{\circ} \mathrm{C}$ and regularly declined $\left(2.4^{\circ} \mathrm{C}\right.$ weekly) to get a persistent temperature of $21-23^{\circ} \mathrm{C}$ at the age of 28 days. Throughout the period of the experiment, lighting regime and relative humidity were maintained in 23:1 h of light: darkness and 50\%-60\%, respectively. The chickens had unlimited access to feed and water during the experiment.

\section{Diet Formulation and Experimental Design}

Amaranth grain (Amaranthus hybridus, variety Ultra) was obtained from Agricultural and Natural Resource Research Center of Alborz Province (Karaj, Iran). Before formulating diets, the chemical composition of main feed ingredients including maize, soybean meal, and amaranth grain were analyzed according to the AOAC procedures (AOAC, 2005) and the data were used to formulate the experimental diets. Male broiler chicks at the age of seven were arbitrarily allocated to 4 treatments that contained 5 replicates of 20 birds. Four

Table 1. Ingredients of feed and nutritional structure of experimental pellet diets

\begin{tabular}{|c|c|c|c|c|c|c|c|c|c|}
\hline \multirow{3}{*}{ Item } & \multirow{3}{*}{ Day 1-6 } & \multicolumn{4}{|c|}{ Day 7-21 } & \multicolumn{4}{|c|}{ Day 22-42 } \\
\hline & & \multicolumn{4}{|c|}{ Amaranth grain in diet (\%) } & \multicolumn{4}{|c|}{ Amaranth grain in diet (\%) } \\
\hline & & 0 & 2 & 4 & 6 & 0 & 2 & 4 & 6 \\
\hline \multicolumn{10}{|l|}{ Ingredients (g/kg) } \\
\hline Maize grain & 560.0 & 560.0 & 541.0 & 524.1 & 507.4 & 610.0 & 596.0 & 577.0 & 558.0 \\
\hline Soybean meal (44\% crude protein) & 383.5 & 383.5 & 382.5 & 378.0 & 375.0 & 330.0 & 324.0 & 322.0 & 320.0 \\
\hline Soybean oil & 14.5 & 14.5 & 15.6 & 17.0 & 17.2 & 22.5 & 22.5 & 23.5 & 24.5 \\
\hline Amaranth grain & - & - & 20.0 & 40.0 & 60.0 & - & 20.0 & 40.0 & 60.0 \\
\hline Limestone & 12.0 & 12.0 & 11.5 & 11.5 & 11.5 & 10.0 & 10.0 & 10.0 & 10.0 \\
\hline Dicalcium phosphate & 18.0 & 18.0 & 17.5 & 17.5 & 17.0 & 16.5 & 16.5 & 16.5 & 16.5 \\
\hline Common salt & 2.1 & 2.1 & 2.1 & 2.1 & 2.1 & 2.1 & 2.1 & 2.1 & 2.1 \\
\hline Bicarbonate sodium & 2.5 & 2.5 & 2.5 & 2.5 & 2.5 & 2.5 & 2.5 & 2.5 & 2.5 \\
\hline Premix of vitamin-mineral ${ }^{a}$ & 5.0 & 5.0 & 5.0 & 5.0 & 5.0 & 5.0 & 5.0 & 5.0 & 5.0 \\
\hline DL- Methionine 99\% & 2.2 & 2.2 & 2.2 & 2.2 & 2.2 & 1.4 & 1.4 & 1.4 & 1.4 \\
\hline L- Lysine & 0.2 & 0.2 & 0.1 & 0.1 & 0.1 & - & - & - & - \\
\hline \multicolumn{10}{|l|}{ Nutrient composition ${ }^{\mathrm{b}}$} \\
\hline Metabolizable energy (MJ/kg) & 11.8 & 11.8 & 11.8 & 11.8 & 11.8 & 12.3 & 12.3 & 12.3 & 12.3 \\
\hline Crude protein (g/kg) & 215.0 & 215.0 & 215.8 & 215.4 & 215.6 & 194.8 & 194.0 & 194.3 & 194.0 \\
\hline Calcium (g/kg) & 9.7 & 9.7 & 9.4 & 9.4 & 9.4 & 8.5 & 8.5 & 8.5 & 8.6 \\
\hline Available phosphorus (g/kg) & 4.6 & 4.6 & 4.5 & 4.6 & 4.5 & 4.2 & 4.2 & 4.3 & 4.4 \\
\hline Sodium (g/kg) & 1.7 & 1.7 & 1.6 & 1.6 & 1.7 & 1.7 & 1.7 & 1.7 & 1.7 \\
\hline Lysine (g/kg) & 11.3 & 11.3 & 11.3 & 11.2 & 11.3 & 9.8 & 9.7 & 9.8 & 9.8 \\
\hline Methionine+Cystine $(\mathrm{g} / \mathrm{kg})$ & 8.6 & 8.6 & 8.6 & 8.6 & 8.7 & 7.3 & 7.3 & 7.3 & 7.4 \\
\hline
\end{tabular}

Note: aTo supply certain amount of minerals and vitamins per kilogram of diet (vitamin D3: 4500 IU; vitamin A: 18100 IU; vitamin K3: 6 mg; vitamin E: $38 \mathrm{mg}$; thiamine: $2.99 \mathrm{mg}$; vitamin B12: $1.7 \mathrm{mg}$; niacin: $58 \mathrm{mg}$; riboflavin: $7.6 \mathrm{mg}$; pyridoxine: $4.55 \mathrm{mg}$; folic acid: $1.8 \mathrm{mg}$; biotin: $0.19 \mathrm{mg}$; ethoxyquin: $0.128 \mathrm{mg}$; pantothenic acid: $17.9 \mathrm{mg}$; cyanocobalamin: $0.02 \mathrm{mg}$; choline chloride: $487.5 \mathrm{mg}$; Fe-sulfate: $40.5 \mathrm{mg}$; Mn-sulfate: $160 \mathrm{mg}$; Zn-sulfate: $84 \mathrm{mg}$; iodine (calcium iodate): $1.26 \mathrm{mg}$; Cu-sulfate: $20 \mathrm{mg}$; and selenium (sodium selenite): $0.31 \mathrm{mg}$ );

bDetermined by feed individual analysis and applied result for calculating nutritious composition. 
levels of amaranth grain ( $0 \%$ (control), $2 \%, 4 \%$, and $6 \%$ ) were included in the dietary treatments (Table 1 ). Dietary treatments were exposed to the steam pelleting process using a California press form pelleting apparatus (Simon Barron Firm, England) in Roshd-Daneh Animal and Poultry Feed Company (Karaj, Iran). The steam was applied at the pressure of $5.3 \mathrm{~kg} / \mathrm{cm}^{2}$ and the average pelleting temperature was about $72^{\circ} \mathrm{C}$. All diets contained a similar amount of energy and protein and formulated based on Ross 308 recommendations (Aviagen, 2014).

\section{Data and Sample Collection}

Performance variables including feed intake (FI) and body weight (BW) were recorded weekly. The difference between given and residual feed was considered as FI. Mortality was recorded daily and data including feed conversion ratio (FCR), average daily gain (ADG), and average daily feed intake (ADFI) were corrected based on it. The amount of feed needed to increase the live BW unit was considered as FCR. This variable was calculated as the ratio of ADFI to ADG during particular period of time. The ADG, ADFI, and FCR were calculated for days 7 to 21, 22 to 42 , and 7 to 42 days of age.

At the end of the experiment (42 days of age), 30 birds from each treatment (6 birds/pen which had close weight to the average of the pen) were chosen. They were weighed and slaughtered after $3 \mathrm{~h}$ fasting; then the slaughtered birds were plucked and visceral organs were excised to determine the relative weight of carcass and organs. Carcass was obtained by removing the head, feathers, feet, and visceral organs. Carcass, breast, legs, and visceral organ weights were determined by weighing scale (00.001 g, model GF 400; A\&D Weighing, San Jose, CA, USA) to calculate carcass and organs relative weight $(\mathrm{g} / 100 \mathrm{~g}$ of live body weight). Twocentimeter portions of the jejunum were taken from the midpoint between pancreo-biliary ducts and Meckel's diverticulum and washed by $0.9 \%$ saline solution to eliminate the jejunal contents. Then, these portions were fixed in a $10 \%$ formalin solution for subsequent morphological assay. The formalin solutions were replaced after $24 \mathrm{~h}$, then samples were kept until morphological study.

At the end of the experiment (day 42), European broiler index (EBI) of broiler chicks (including the sacrificed birds), was calculated through the following formula (Marcu et al., 2013):

$\mathrm{EBI}=[$ livability $(\%) \times$ average daily gain $(\mathrm{g})] /$

[feed coversion ratio $(\mathrm{g} / \mathrm{g}) \times 10$ ]

Intestinal tissue samples were transferred from formaldehyde, after dehydration by passing tissue through a series of alcohol solutions; they were then cleared in xylene and embedded in paraffin. Chemicals were obtained from Sigma-Aldrich Company (St. Louis, MO). Leica Rotary Microtome (RM 2145, Wetzlar, Germany) was used to cut $5 \mathrm{~mm}$ longitudinal sections. After that, the sections were placed on glass slides and stained with haematoxylin-eosin, as described by Ebrahimi et al. (2017). To calculate the morphometric variables, micrographs were taken with Olympus light microscope BX44 (Tokyo, Japan) applying Epix XCAP software (Buffalo Grove, IL, USA).

Ten intact and vertically located villi were selected from each sample and considered for morphological assay. The measured variables were included: villus width (evaluated at the mid-point of villus), villus height (from the top of the villus to the junction of villus and crypt), and crypt depth (determined from the junction of villus and crypt to the base of the crypt). The surface area of villus was calculated through the following formula (Sakamoto et al., 2000): $2 \pi \times(\mathrm{VW} / 2) \times \mathrm{VH}$, in this formula: VW was villus width, $\mathrm{VH}$ was villus height, and $\pi$ was 3.14 .

On day 40, 6 birds/replicate were selected and bled via wing vein using sterile syringes $(2 \mathrm{~mL})$. Obtained blood samples were exposed to centrifuge $(3000 \times \mathrm{g}$ for $15 \mathrm{~min}$ ) to separate serum. Then serum samples were kept at $-20^{\circ} \mathrm{C}$ until metabolite analysis was carried out. A commercial laboratory kit (Parsazmoon, Iran) and god-pap method were applied to determine the glucose concentration as $\mathrm{mg} / \mathrm{dL}$ at $546 \mathrm{~nm}$ wavelengths (Datar et al., 2006). The concentrations of cholesterol, triglyceride, low- and high-density lipoproteins (LDL and HDL) were determined using commercial laboratory kits (Parsazmoon, Iran) and methods described by Friedewald et al. (1972) and Gordon \& Amer (1977).

\section{Statistical Analysis}

The GLM procedures of SAS 9.1 software (SAS, 2003) were used to analyze data in a completely randomized design. For each treatment, there were 5 replicates for performance traits (20 birds/pen) and 30 samples for carcass characteristics, morphological traits, and blood variables (six birds/pen). Values in percentage were first transformed to arcsine. The pen of birds functioned as the experimental unit. Duncan's multiple range test was applied for comparing the means (Duncan, 1955). Performance traits were analyzed considering seven-day-old body weight as a covariate. To determine linear and quadratic relationships among treatments, orthogonal contrasts were performed. Differences were considered to be statistically significant at $\mathrm{p}<0.05$.

\section{RESULTS}

\section{Chemical Analysis of Amaranth}

Table 2 shows the chemical compositions including crude protein, ether extract, dry matter, nitrogen-free extract, ash, crude fiber, calcium, available phosphorus, selected anti nutrient factors, and content of amino acid in the experimental diet pellet contained amaranth grain.

\section{Growth Performance}

As Table 3 shows, dietary supplementation of amaranth had a quadratically significant effect $(p \leq 0.05)$ on BW (d 42) and ADG (d 22-42 and 7-42). The results showed the increased $\mathrm{BW}$ of chicks receiving $2 \%$ ama- 
ranth grain compared to the other groups at the ages of 21 and 42 days $(\mathrm{p}<0.05)$. On day 42, chicks fed with $6 \%$ amaranth grain showed lower $\mathrm{BW}$ in comparison with birds receiving $2 \%$ amaranth and the control $(p<0.05)$. No significant difference was observed among the experimental groups regarding ADFI ( $p>0.05)$. Considering the whole period of the experiment (days $7-42$ ), birds fed with $2 \%$ amaranth grain showed significantly higher ADG than the other groups, but those receiving $4 \%$ and $6 \%$ amaranth showed lower ADG than the birds fed with $2 \%$ amaranth $(\mathrm{p}<0.05)$. The addition of $4 \%$ or $6 \%$ amaranth grain into diets linearly increased FCR and decreased EBI $(p<0.05)$, but no difference was detected between chicks fed with $2 \%$ amaranth and the control regarding FCR and EBI $(p>0.05)$. The total liv- ability percentage was 90.75 , and this variable was not influenced by dietary treatments.

\section{Carcass Yield and Relative Weight of Organs}

Table 4 presents the effects of amaranth grain in a pellet diet on carcass yield and relative weight of organs on day 42. The effects of dietary addition of amaranth on carcass yields and relative weights of abdominal fat and liver were quadratically significant $(p<0.05)$. Birds receiving $6 \%$ amaranth grain showed decrease percentages of carcass yield and liver compared to those fed with $2 \%$ or $4 \%$ amaranth $(\mathrm{p}<0.05)$; however, there was no significant difference in these variables between chicks receiving $6 \%$ amaranth and the control $(p>0.05)$.

Table 2. Chemical compositions of amaranth grain used in this experiment ${ }^{\mathrm{a}}$

\begin{tabular}{lclc}
\hline Item & Value & Amino acids & Value \\
\hline Dry matter $(\mathrm{g} / \mathrm{kg})$ & 900.8 & Lysine $(\mathrm{g} / \mathrm{kg})$ & 7.5 \\
Crude protein $(\mathrm{g} / \mathrm{kg})$ & 143.1 & Methionine $(\mathrm{g} / \mathrm{kg})$ & 2.1 \\
Ether Extract $(\mathrm{g} / \mathrm{kg})$ & 71.5 & Cysteine $(\mathrm{g} / \mathrm{kg})$ & 3.63 \\
Nitrogen-free extract $(\mathrm{g} / \mathrm{kg})$ & 599.1 & Threonine $(\mathrm{g} / \mathrm{kg})$ & 4.8 \\
Crude fiber $(\mathrm{g} / \mathrm{kg})$ & 45.0 & Arginine $(\mathrm{g} / \mathrm{kg})$ & 10.5 \\
Ash $(\mathrm{g} / \mathrm{kg})$ & 33.7 & Isoleucine $(\mathrm{g} / \mathrm{kg})$ & 6.3 \\
Calcium $(\mathrm{g} / \mathrm{kg})$ & 2.4 & Leucine $(\mathrm{g} / \mathrm{kg})$ & 7.2 \\
Available phosphorus $(\mathrm{g} / \mathrm{kg})$ & 4.1 & Valine $(\mathrm{g} / \mathrm{kg})$ & 6.3 \\
Phytic acid $(\mathrm{g} / \mathrm{kg})$ & 4.3 & Histidine $(\mathrm{g} / \mathrm{kg})$ & 2.6 \\
Gross energy $(\mathrm{MJ} / \mathrm{kg})$ & 13.03 & Phenylalanine $(\mathrm{g} / \mathrm{kg})$ & 5.5 \\
Metabolizable energy (MJ/kg) & 11.40 & Serine $(\mathrm{g} / \mathrm{kg})$ & 9.2 \\
Tannin $(\%$ catechin equivalent) & 0.09 & Proline $(\mathrm{g} / \mathrm{kg})$ & 5.1 \\
Trypsin inhibitor (unit of enzyme) & 4.05 & Glycine $(\mathrm{g} / \mathrm{kg})$ & 11.1 \\
\hline
\end{tabular}

Note: aChemical compositions of amaranth grain determined in a lab based on AOAC (2000) methods, metabolizable energy amount calculated based on the results.

Table 3. Performances of broiler chicks fed pellet diet containing amaranth grain

\begin{tabular}{|c|c|c|c|c|c|c|c|c|}
\hline \multirow{2}{*}{ Variables } & \multicolumn{4}{|c|}{ Levels of amaranth grain in diets (\%) } & \multirow{2}{*}{ SEM } & \multirow{2}{*}{ P-value } & \multicolumn{2}{|c|}{ Contrasts } \\
\hline & 0 (control) & 2 & 4 & 6 & & & Linear & Quadratic \\
\hline \multicolumn{9}{|l|}{ BW (g) } \\
\hline $\mathrm{d} 21$ & $558.91^{\mathrm{b}}$ & $616.83^{a}$ & $526.51^{b}$ & $574.03^{\mathrm{ab}}$ & 10.79 & 0.014 & 0.563 & 0.765 \\
\hline $\mathrm{d} 42$ & $2028.62^{b}$ & $2291.24^{a}$ & $1968.22^{\mathrm{bc}}$ & $1884.41^{\mathrm{c}}$ & 39.31 & $<0.001$ & 0.001 & $<0.001$ \\
\hline \multicolumn{9}{|l|}{$\operatorname{ADFI}(\mathrm{g} / \mathrm{d} / \mathrm{bird})$} \\
\hline d 7-21 & 46.71 & 49.03 & 44.43 & 46.22 & 0.78 & 0.219 & 0.362 & 0.846 \\
\hline d 22-42 & 114.52 & 119.24 & 123.44 & 124.21 & 2.54 & 0.537 & 0.531 & 0.194 \\
\hline d $7-42$ & 85.81 & 90.42 & 88.24 & 87.93 & 1.18 & 0.636 & 0.721 & 0.334 \\
\hline \multicolumn{9}{|l|}{ ADG (g/d/ bird) } \\
\hline d $7-21$ & 28.81 & 31.03 & 24.74 & 29.12 & 0.87 & 0.057 & 0.436 & 0.504 \\
\hline d 22-42 & $66.92^{\mathrm{b}}$ & $77.04^{\mathrm{a}}$ & $63.03^{b c}$ & $60.81^{c}$ & 1.66 & $<0.001$ & 0.001 & 0.005 \\
\hline d 7-42 & $50.71^{\mathrm{b}}$ & $56.42^{\mathrm{a}}$ & $45.84^{c}$ & $47.23^{\mathrm{bc}}$ & 1.14 & $<0.001$ & 0.004 & 0.008 \\
\hline \multicolumn{9}{|l|}{ FCR $(g / g)$} \\
\hline d $7-21$ & 1.63 & 1.60 & 1.80 & 1.59 & 0.03 & 0.090 & 0.825 & 0.146 \\
\hline d 22-42 & $1.71^{\mathrm{b}}$ & $1.60^{\mathrm{b}}$ & $1.96^{\mathrm{a}}$ & $1.96^{\mathrm{a}}$ & 0.04 & 0.001 & $<0.001$ & 0.342 \\
\hline d $7-42$ & $1.69^{\mathrm{b}}$ & $1.60^{\mathrm{b}}$ & $1.92^{\mathrm{a}}$ & $1.86^{\mathrm{a}}$ & 0.03 & $<0.001$ & 0.001 & 0.757 \\
\hline Livability (d 7-42), \% & 930.00 & 89.20 & 89.80 & 910.00 & 1.83 & 0.907 & 0.762 & 0.533 \\
\hline EBI (d 7-42) & $280.61^{\mathrm{ab}}$ & $318.44^{\mathrm{a}}$ & $215.72^{\mathrm{b}}$ & $230.83^{b}$ & 13.95 & 0.020 & 0.024 & 0.622 \\
\hline
\end{tabular}

Note: $\mathrm{BW}=$ body weight; $\mathrm{ADFI}=$ average daily feed intake; $\mathrm{ADG}=$ average daily gain; $\mathrm{FCR}=$ feed conversion ratio; $\mathrm{EBI}=\mathrm{E}$ (ropean broiler index; $\mathrm{SEM}=$ Pooled standard error of the mean. Means in the same row with different superscripts differ significantly $(p<0.05)$. 
The addition of amaranth grain in the pellet diet significantly reduced abdominal fat percentage compared to the control $(\mathrm{p}<0.05)$ and the lowest percentage was observed in birds receiving $6 \%$ amaranth grain. Other organs' relative weights were not influenced by dietary treatments.

\section{Intestinal Histomorphology}

Table 5 shows the effects of amaranth grain in a pellet diet on the morphology of jejunum in broiler chicks on day 42. Dietary inclusion of amaranth grain affected none of the morphological variables in jejunum; meanwhile, the greatest and least numerical values of villus surface area, villus height, and villus height to crypt depth ratio were observed in birds fed with $2 \%$ and $4 \%$ amaranth, respectively.

\section{Hematological Analysis}

Table 6 summarizes the effects of amaranth grain in a pellet diet on selected blood variables of broilers on day 40. Most of the blood variables evaluated in this experiment were not significantly affected by dietary treatments $(p>0.05)$ except cholesterol and LDL. The concentrations of LDL and cholesterol in the serum of broilers were linearly decreased with the increased dietary inclusion level of amaranth grain in the experimental pellet ration $(\mathrm{p}<0.05)$.

\section{DISCUSSION}

The results of amaranth chemical analysis were in agreement with the data published in the previous study (Ravindran et al., 1996). Improvement of produc-

Table 4. Carcass yield and organs relative weights ( $\mathrm{g} / 100 \mathrm{~g}$ of live body weight) of 42 day-old broiler chicks fed pellet diet containing amaranth grain

\begin{tabular}{|c|c|c|c|c|c|c|c|c|}
\hline \multirow{2}{*}{ Variables } & \multicolumn{4}{|c|}{ Levels of amaranth grain in diets (\%) } & \multirow{2}{*}{ SEM } & \multirow{2}{*}{$\mathrm{P}$-value } & \multicolumn{2}{|c|}{ Contrasts } \\
\hline & 0 (control) & 2 & 4 & 6 & & & Linear & Quadratic \\
\hline Carcass yield & $73.87^{\mathrm{ab}}$ & $74.42^{\mathrm{a}}$ & $74.67^{\mathrm{a}}$ & $72.15^{\mathrm{b}}$ & 0.34 & 0.036 & 0.094 & 0.021 \\
\hline Breast & 25.04 & 25.47 & 25.72 & 23.99 & 0.31 & 0.205 & 0.286 & 0.083 \\
\hline Legs & 19.64 & 19.65 & 19.16 & 19.41 & 0.15 & 0.646 & 0.400 & 0.707 \\
\hline Back and neck & 20.63 & 20.70 & 21.26 & 20.94 & 0.17 & 0.683 & 0.408 & 0.635 \\
\hline Heart & 0.49 & 0.48 & 0.50 & 0.48 & 0.01 & 0.970 & 0.997 & 0.858 \\
\hline Liver & $1.98^{\mathrm{ab}}$ & $2.15^{\mathrm{a}}$ & $2.09^{a}$ & $1.85^{\mathrm{b}}$ & 0.03 & 0.014 & 0.137 & 0.003 \\
\hline Pancreas & 0.20 & 0.23 & 0.38 & 0.20 & 0.04 & 0.437 & 0.694 & 0.265 \\
\hline Gall bladder & 0.07 & 0.05 & 0.06 & 0.09 & 0.005 & 0.136 & 0.432 & 0.088 \\
\hline Gizzard & 1.88 & 1.65 & 1.81 & 1.72 & 0.07 & 0.686 & 0.634 & 0.640 \\
\hline Bursa of Fabricious & 0.08 & 0.06 & 0.08 & 0.09 & 0.006 & 0.303 & 0.154 & 0.302 \\
\hline Spleen & 0.12 & 0.11 & 0.12 & 0.12 & 0.004 & 0.608 & 0.861 & 0.341 \\
\hline Abdominal fat & $1.65^{\mathrm{a}}$ & $1.11^{\mathrm{bc}}$ & $1.16^{\mathrm{b}}$ & $0.79^{c}$ & 0.07 & $\leq 0.001$ & 0.031 & 0.002 \\
\hline
\end{tabular}

Note: SEM= Pooled standard error of the mean. Means in the same row with different superscripts differ significantly (p<0.05).

Table 5. Morphological indices of jejunum in 42 day-old broiler chicks fed pellet diet containing amaranth grain

\begin{tabular}{|c|c|c|c|c|c|c|c|c|}
\hline \multirow{2}{*}{ Variables } & \multicolumn{4}{|c|}{ Levels of amaranth grain in diets (\%) } & \multirow{2}{*}{ SEM } & \multirow{2}{*}{ P-value } & \multicolumn{2}{|c|}{ Contrasts } \\
\hline & 0 (control) & 2 & 4 & 6 & & & Linear & Quadratic \\
\hline Villus height $(\mu \mathrm{m})$ & 1273.11 & 1347.03 & 1067.12 & 1122.24 & 72.98 & 0.541 & 0.295 & 0.951 \\
\hline Villus width $(\mu \mathrm{m})$ & 147.52 & 153.01 & 137.54 & 149.03 & 4.52 & 0.706 & 0.802 & 0.759 \\
\hline Crypt depth ( $\mu \mathrm{m})$ & 223.94 & 223.12 & 219.31 & 220.13 & 2.70 & 0.931 & 0.576 & 0.889 \\
\hline Villus surface area $\left(\times 10^{-3}, \mu \mathrm{m}^{2}\right)$ & 559.01 & 645.41 & 467.32 & 529.32 & 42.80 & 0.517 & 0.341 & 0.930 \\
\hline Villus height to crypt depth ratio & 5.6 & 6.0 & 4.8 & 5.1 & 0.31 & 0.548 & 0.333 & 0.985 \\
\hline
\end{tabular}

Note: SEM= Pooled standard error of the mean. Means in the same row with different superscripts differ significantly (p<0.05).

Table 6. Selected blood variables of 40 day-old broiler chicks fed pellet diet containing amaranth grain

\begin{tabular}{|c|c|c|c|c|c|c|c|c|}
\hline \multirow{2}{*}{ Variables (mg/dL) } & \multicolumn{4}{|c|}{ Levels of amaranth grain in diets (\%) } & \multirow{2}{*}{ SEM } & \multirow{2}{*}{ P-value } & \multicolumn{2}{|c|}{ Contrasts } \\
\hline & 0 (control) & 2 & 4 & 6 & & & Linear & Quadratic \\
\hline Glucose & 143.80 & 123.20 & 132.00 & 133.70 & 4.47 & 0.459 & 0.596 & 0.223 \\
\hline Total protein & 3.20 & 3.20 & 3.50 & 3.00 & 0.09 & 0.287 & 0.712 & 0.174 \\
\hline Triglyceride & 71.70 & 66.00 & 81.20 & 82.00 & 2.84 & 0.134 & 0.068 & 0.557 \\
\hline Cholesterol & $112.00 \mathrm{a}$ & $88.90 b$ & $94.30 \mathrm{~b}$ & $89.30 b$ & 2.88 & 0.009 & 0.003 & 0.086 \\
\hline High density lipoprotein (HDL) & 51.20 & 51.60 & 51.00 & 51.00 & 0.11 & 0.206 & 0.238 & 0.377 \\
\hline Low density lipoprotein (LDL) & $160.00 \mathrm{a}$ & $158.00 \mathrm{ab}$ & $157.20 \mathrm{~b}$ & $157.20 \mathrm{~b}$ & 0.40 & 0.042 & 0.010 & 0.196 \\
\hline
\end{tabular}

Note: $S E M=$ Pooled standard error of the mean. Means in the same row with different superscripts differ significantly ( $<<0.05)$. 
tive traits using limited amount of amaranth in diet was consistent with the studies conducted by Rouckova et al. (2004) and Orczewska-Dudek et al. (2018). This result can be related to a high nutritional value, balanced amino acid profile, and also heat treatment of amaranth which can lead to partial degradation of antinutrients like tannin (Siwatch \& Yadav, 2017; Thakur \& Kumar, 2019). It must be mentioned that Pisarikova et al. (2006) replaced amaranth grain (raw and popped) with meat and bone meal (up $8 \%$ of diet) without any negative effects on performance traits including BW, FI, and FCR. Reduced BW, ADG, EBI, and impaired FCR by dietary inclusion of $4 \%$ or $6 \%$ amaranth in the present study were similar to the results of Yaghobfar et al. (2014) which reported retarded growth of broilers when using more than $5 \%$ of amaranth in diet. This may imply that heat-processing conducted in this experiment was not hard enough to degrade the antinutrient content of this variety of amaranth at levels more than $2 \%$. However, it seemed to be helpful for $2 \%$ inclusion of this grain.

Reduced amount of abdominal fat percentage observed in the birds fed with $6 \%$ amaranth was in agreement with the results of Orczewska-Dudek et al. (2018) and may be attributed to the considerable amounts of 20-Hydroxyecdysone which have been received in this treatment. 20-Hydroxyecdysone is a phytochemical of quinoa and amaranth, reported to regulate protein synthesis, blood glucose levels, and to have anti-obesity effect (Tang \& Tsao, 2017). However, these researchers stated that further studies are necessary, particularly for deepening the existent knowledge about the effect of amaranth on the prevention of fat deposition and the associated mechanisms.

Rouckova et al. (2004) observed that boilers' carcass yield receiving $7 \%$ amaranth grain was significantly lesser than the control $(\mathrm{p} \leq 0.05)$. Conversely, Pisarikova et al. (2006) did not report any significant effect of using $8 \%$ amaranth on carcass and abdominal fat yield. In their report, the liver, heart, and stomach yields were significantly higher in the bird fed with dried above-ground amaranth grain compared to the control. Moreover, Szczerbińska et al. (2015) demonstrated that the liver's relative weights in Japanese quails fed with $4 \%$ or $7 \%$ amaranth were higher than control, even though they were not statistically significant. Minor morphological changes have been shown in birds' livers receiving amaranth (Kabuage et al., 2002). A similar process might have happened in our study and resulted in the liver's lower relative weight when using a high level of amaranth grain in the diet; however, there were no obvious anomalies within the birds' internal organs. Inconsistency of our results with the others is not easy to interpret; however, it may be related to different amaranth varieties, antinutrient content, or processing applied in different experiments. The more antinutrient content is available in the plant protein sources of diet, and the less performance efficiency will be obtained at the end of the poultry production period (Gamel et al., 2006).

The authors could not find any report regarding the effect of amaranth on the intestinal morphology in poul- try. However, it is known that antinutritional factors, like tannin and trypsin inhibitor (found in feedstuff), impair gastrointestinal development and destroy the intestinal microvilli of animals (Rocha et al., 2014; Beski et al., 2015). There was no significant adverse effect on the villus health and absorbance area of broilers by dietary inclusion of amaranth grain in the present study. This found result is possibly due to the heat-treatment process which may be efficient enough to cover or alleviate the harmful effects of antinutrients on the intestinal morphology. As previously noted, treatments (such as popping, pelleting, etc.) can relatively degrade antinutritional compounds in the feedstuff (Siwatch \& Yadav, 2017; Thakur \& Kumar, 2019).

Some reports have revealed that the dietary addition of amaranth can reduce the blood concentrations of cholesterol fragments (LDL and VLDL), in animals including rabbit (Caselato-Sousa et al., 2014), hamsters (Chmelik et al., 2019), and rats (Lado et al., 2015). In another study, Longato et al. (2015) reported that the dietary inclusion of amaranth grain (5\% and 10\%) significantly decreased serum levels of triglycerides and cholesterol in broiler chickens compared to the control group. Amaranth seeds contain a considerable amount of a valuable compound named squalene. Squalene is a superior antioxidant triterpene recognized for its extensive biological efficacy, especially against hypercholesterolemia (Hein et al., 2017), cancer (Kotelevets et al., 2017); and also as a cardio-protectant (Ibrahim et al., 2020). In addition, Salvamani et al. (2016) introduced plant amaranth as a powerful inhibitor of HMG-CoA reductase enzyme. This finding is very relevant since this specific enzyme is the target for hypercholesterolemia occurrence. Herbal components that inhibit or reduce the HMG-CoA reductase activity may possibly be applied as an agent of hypocholesterolemia. The lowered concentration of LDL in sera was in agreement with less fat deposition observed in the birds receiving amaranth grain. Due to the association of cholesterol intakes and coronary heart disease (Li et al., 2015), decreased serum LDL levels in poultry would be advantageous for the broiler-meat-consumers. It is suggested to conduct more studies about this grain and its processing in poultry nutrition all over the world, especially in the tropical and subtropical regions challenging with drought and severe climate change.

\section{CONCLUSION}

Dietary inclusion of amaranth grain (Amaranthus hybridus) in pellet diet up to the level of $2 \%$ can improve productive traits of broiler chickens and reduce serum cholesterol and LDL levels which may have healthful effects on the birds and broiler-meat-consumers.

\section{CONFLICT OF INTEREST}

No potential conflict of interest was stated by the authors. 


\section{ACKNOWLEDGEMENT}

We impressively appreciate the spiritual and financial support of this research from the president of the Animal Science Research Institute of Iran, Karaj and the Ministry of Agriculture (Jahad-e-Keshavarzi) (Project code: 960455-083-13-13-2).

\section{REFERENCES}

AOAC. 2005. Official Methods of Analysis of AOAC International. $18^{\text {th }}$ ed. Assoc. Off. Anal. Chem., Arlington, USA.

Aviagen. 2014. Ross 308: broiler nutrition specifications. http://en.aviagen.com/assets/Tech_Center/Ross_Broiler/ Ross308BroilerNutritionSpecs2014-EN.pdf. $\left[12^{-}\right.$April 2016].

Beski, S. S. M., R. A. Swick, \& P. A. Iji. 2015. Specialized protein products in broiler chicken nutrition: A review. Anim. Nutr. 1: 47-53. https://doi.org/10.1016/j.aninu.2015.05.005

Borelli, T., D. Hunter, S. Padulosi, N. Amaya, G. Meldrum, D. M. D. O. Beltrame, G. Samarasinghe, V. W. Wasike, B. Güner, A. Tan, Y. K. Dembele, G. Lochetti, A. Sidibe, \& F. Tartanac. 2020. Local solutions for sustainable food systems: The contribution of orphan crops and wild edible species. Agronomy. 10: 231. https://doi.org/10.3390/ agronomy10020231

Caselato-Sousa, V. M., M. R. Ozaki, E. A. de Almeida, \& J. Amaya-Farfan. 2014. Intake of heat-expanded amaranth grain reverses endothelial dysfunction in hypercholesterolemic rabbits. Food Func. 5: 3281-3286. https://doi. org/10.1039/C4FO00468J

Chmelik, Z., M. Snejdrlova, \& M. Vrablík. 2019. Amaranth as a potential dietary adjunct of lifestyle modification to improve cardiovascular risk profile. Nutr. Res. 72: 36-45. https://doi.org/10.1016/j.nutres.2019.09.006

Datar, S. P., D. S. Suryavanshi, \& R. R. Bhonde. 2006. Chick pancreatic $\mathrm{B}$ islets as an alternative in vitro model for screening insulin secretagogues. Poult. Sci. 85: 2260-2264. https://doi.org/10.1093/ps/85.12.2260

Duncan, D. B. 1955. Multiple range and multiple F-test. Biometrics. 11: 1-42. https://doi.org/10.2307/3001478

Ebrahimi, E., R. S. Sobhani, \& H. Zarghi. 2017. Effect of triticale level and exogenous enzyme in the grower diet on performance, gastrointestinal tract relative weight, jejunal morphology and blood lipids of Japanese quail (Coturnix coturnix Japonica). J. Agr. Sci. Tech. 19: 569-580.

Friedewald, W. T., R. I. Levy, \& D. S. Fredrickson. 1972. Estimation of the concentration of LDL cholesterol in plasma, without use of the preparative ultracentrifuge. Clin. Chem. 18: 499-504. https://doi.org/10.1093/ clinchem/18.6.499

Gamel, T. H., J. P. Linssen, A. S. Mesallam, A. A. Damir, \& L. A. Shekib. 2006. Seed treatments affect functional and antinutritional properties of amaranth flours. J. Sci. Food Agric. 86: 1095-102. https://doi.org/10.1002/jsfa.2463

Gordon, T., \& M. Amer. 1977. Cardiovascular disease marker. Am. J. Med. 62: 707-714. https://doi. org/10.1016/0002-9343(77)90874-9

Hein, H. T. M., N. C. Ha, L. T. Thom, \& D. D. Hong. 2017. Squalene promotes cholesterol homeostasis in macrophage and hepatocyte cells via activation of liver $X$ receptor (LXR) $\alpha$ and $\beta$. Biotechnol. Lett. 39: 1101-1107. https:// doi.org/10.1007/s10529-017-2345-y

Ibrahim, N., S. Fairus, M. S. Zulfarina, \& I. N. Mohamed. 2020. The efficacy of squalene in cardiovascular disease risk-a systematic review. Nutrients. 12: 414. https://doi. org/10.3390/nu12020414
Kabuage, L.W., P.N. Mbugua, B. N. Mitaru, \& T. A. Ngatia. 2002. Effect of steam pelleting and inclusion of molasses in amaranth diets on broiler chicken performance, carcass composition and histopathology of some internal organs. http://www.fao.org/docrep/ARTICLE/AGRIPPA/550_ EN.HTM. [15 February 2017].

Kotelevets, L., E. Chastre, J. Caron, J. Mougin, G. Bastian, A. Pineau, F. Walker, T. Lehy, D. Desmaele, \& P. Couvreur. 2017. A squalene-based nanomedicine for oral treatment of colon cancer. Cancer Res. 77: 2964-2975. https://doi. org/10.1158/0008-5472.CAN-16-1741

Lado, M. B., J. Burini, G. Rinaldi, M. C. Anon, \& V. A. Tironi. 2015. Effects of the dietary addition of amaranth (Amaranthus mantegazzianus) protein isolate on antioxidant status, lipid profiles and blood pressure of rats. Plant Foods Hum. Nutr. 70: 371-379. https://doi.org/10.1007/ s11130-015-0516-3

Li, Y., A. Hruby, A. M. Bernstein, S. H. Ley, D. D. Wang, S. E. Chiuve, L. Sampson, K. M. Rexrode, E. B. Rimm, W. C. Willett, \& F. B. Hu. 2015. Saturated fats compared with unsaturated fats and sources of carbohydrates in relation to risk of coronary heart disease: a prospective cohort study. J. Am. Coll. Cardiol. 66: 1538-1548. https://doi. org/10.1016/j.jacc.2015.07.055

Longato, E., G. Meineri, P. G. Peiretti, \& P. P. Mussa. 2015. Effects of diets containing linseed oil and supplemented with grain amaranth (Amaranthus caudatus) on growth performances, oxidative status and serum biochemical parameters in broilers. Ital. J. Anim. Sci. 14: 18 (Abtr.).

Lopez, D. N., Galante, M., Robson, M. Boeris, V., \& D. Spelzini. 2018. Amaranth, quinoa and chia protein isolates: Physicochemical and structural properties. Int. J. Biol. Macromol. 109: 152-159. https://doi.org/10.1016/j. ijbiomac.2017.12.080

Marcu, A., I. Vacaru-Opriş, G. Dumitrescu, L. Petculescu Ciochină, A. Marcu, M. Nicula, I. Peț, D. Dronca, B. Kelciov \& C. Mariş. 2013. The influence of genetics on economic efficiency of broiler chickens growth. Anim. Sci. Biotechnol. 46: 339-346.

Martinez-Lopez, A., M. C. Millan-Linares, N. M. RodriguezMartin, F. Millan, \& S. M. la Paz. 2020. Nutraceutical value of kiwicha (Amaranthus caudatus L.). J. Functional Food. 65: 103735. https://doi.org/10.1016/j.jff.2019.103735

Martinez-Nunez, M., M. Ruiz-Rivas, P. F. Vera-Hernandez, R. Bernal-Munoz, S. Luna-Suarez, \& F. F. Rosas-Cardenas. 2019. The phenological growth stages of different amaranth species grown in restricted spaces based in $\mathrm{BBCH}$ code. S. Afr. J. Bot. 124: 436-443. https://doi.org/10.1016/j. sajb.2019.05.035

Molina, E., P. González-Redondo, R. Moreno-Rojas, K. Montero-Quintero, B. Bracho, \& A. Sánchez-Urdaneta. 2015. Effects of diets with Amaranthus dubius Mart. ex Thell. on performance and digestibility of growing rabbits. World Rabbit Sci. 23: 9-18. https://doi.org/10.4995/ wrs.2015.2071

Mota, C., M. Santos, R. Mauro, N. Samman, A. S. Matos, D. Torres \& I. Castanheira. 2014. Protein content and amino acids profile of pseudocereals. Food Chem. 15: 55-61. https://doi.org/10.1016/j.foodchem.2014.11.043

Ndungu, Z. W., E. N. Kuria, N. K. Gikonyo, \& D. K. Mbithe. 2017. Efficacy of amaranth grain consumption on CD4 count and morbidity patterns among adults living with HIV in Nyeri, Kenya. J. AIDS HIV Res. 9: 81-88. https://doi. org/10.5897/JAHR2017.0415

Orczewska-Dudek, S., M. Pietras, \& J. Nowak. 2018. The effect of amaranth seeds, sea buckthorn pomace and black chokeberry pomace in feed mixtures for broiler chickens on productive performance, carcass characteristics and selected indicators of meat quality. Ann. Anim. Sci. 18: 
501-523. https://doi.org/10.2478/aoas-2018-0002

Peiretti, P. G. 2018. Amaranth in animal nutrition: A review. Livest. Res. Rural Dev. 30: article ID 88.

Pisarikova, B., Z. Zraly, S. Kracmar, M. Trckova, \& I. Herzig. 2006. The use of amaranth (genus Amaranthus L.) in the diets for broiler chickens. Veterinarni Medicina. 51: 399-407. https://doi.org/10.17221/5560-VETMED

Ravindran, V., R. L. Hood, R. J. Gill, C. R. Kneale, \& W. L. Bryden. 1996. Nutritional evaluation of grain amaranth (Amaranthus hypochondriacus) in broiler diets. Anim. Feed Sci. Technol. 63: 323-331. https://doi.org/10.1016/ S0377-8401(96)00997-2

Reyes, M. F., J. L. Chavez-Servin, C. Gonzalez-Coria, A. Mercado-Luna, K. T. Carbot, A. Aguilera-Barreyro, R. Ferriz-Martinez, J. Serrano-Arellano, \& T. GarciaGasca. 2018. Comparative account of phenolics, antioxidant capacity, $\alpha$-tocopherol and anti-nutritional factors of Amaranth (Amaranthus hypochondriacus) grown in the greenhouse and open field. Int. J Agric. Biol. 20: 2428-2436. https://doi.org/10.17957/IJAB/15.0786

Rocha, C., J. F. Durau, L. N. E. Barrilli, F. Dahlke, P. Maiorka, \& A. Maiorka. 2014. The effect of raw and roasted soybeans on intestinal health, diet digestibility and pancreas weight of broilers. J. Appl. Poult. Res. 23: 71-79. https://doi. org/10.3382/japr.2013-00829

Rouckova, J., M. Trckova, \& I. Herzig. 2004. The use of amaranth grain in diets for broiler chickens and its effect on performance and selected biochemical indicators. Czech J. Anim. Sci. 49: 532-541. https://doi.org/10.17221/4341-CJAS

Sakamoto, K., H. Hirose \& A. Onizuka. 2000. Quantitative study of changes in intestinal morphology and mucus gel on total parenteral nutrition in rats. J. Surg. Res. 94: 99-106. https://doi.org/10.1006/jsre.2000.5937

Salvamani, S., B. Gunasekaran, M. Y. Shukor, N. A. Shaharuddin, M. K. Sabullah, \& S. A. Ahmad. 2016. Anti-HMG-CoA reductase, antioxidant, and anti-inflammatory activities of Amaranthus viridis leaf extract as a potential treatment for hypercholesterolemia. Evid. Based
Complementary Altern. Med. Article ID: 8090841, 10 pages. https://doi.org/10.1155/2016/8090841

SAS. 2003. User's guide: Statistics Version 9.1. Statistical Analysis Software Institute, Cary, North Carolina, USA.

Shevkani, K., N. Singh, J. Chand-Rana, \& A. Kaur. 2014. Relationship between physicochemical and functional properties of amaranth (Amaranthus hypochondriacus) protein isolates. Int. J. Food Sci. Tech. 49: 541-550. https://doi. org/10.1111/ijfs.12335

Sing, A., R. K. Dubay, A. K. Bundela, \& P. C. Abhilash. 2020. The trilogy of wild crops, traditional agronomic practices, and UN-sustainable development goals. Agronomy. 10: 648. https://doi.org/10.3390/agronomy10050648

Siwatch, M., \& R. B Yadav. 2017. Pseudocereals: Nutritional quality, processing and potential health benefits. Curr. Nutr. Food Sci. 13: 296-230. https://doi.org/10.2174/157340 1313666170214165153

Szczerbinska, D., B. Pyka, E. Szabelska, M. Ligocki, D. Majewska, K. Romaniszyn, \& M. Sulik. 2015. The effect of diet with amaranth (Amaranthus cruentus) seeds on Japanese quail (Coturnix coturnix japonica) performance, somatic development, hatching results and selected blood biochemical parameters. Vet. Med. Zoot. 70: 67-72.

Tang, Y. \& R. Tsao. 2017. Phytochemicals in quinoa and amaranth grains and their antioxidant, anti-inflammatory and potential health beneficial effects: a review. Mol. Nutr. Food Res. 61. Epub. https://doi.org/10.1002/mnfr.201600767

Thakur, P. \& K. Kumar. 2019. Nutritional importance and processing aspects of Pseudo-cereals. J. Agric. Eng. Food Technol. 6: 155-160.

Venskutonis, P. R. \& P. Kraujalis. 2013. Nutritional components of amaranth seeds and vegetables: a review on composition, properties, and uses. Compr. Rev. Food Sci. Food Saf. 12: 381-412. https://doi.org/10.1111/1541-4337.12021

Yaghobfar, A., A. Safamehr, \& H. Ghaderi. 2014. Determination of nutritional values of Amaranthus grain on the broiler performance. Appl. Anim. Sci. Res. J. 3: 43-50. (In Persian). https://doi.org/10.22092/AASRJ.2014.100104 